\title{
Are iron oxide nanoparticles safe? Current knowledge and future perspectives
}

\author{
Vanessa Valdiglesiass $^{\mathrm{a}, 1}$, Natalia Fernández-Bertólez ${ }^{\mathrm{a}, \mathrm{b}, 1}, \mathrm{Gözde} \mathrm{Kiliç}^{\mathrm{c}}$, Carla Costa ${ }^{\mathrm{d}, \mathrm{e}}$, \\ Solange Costa ${ }^{\mathrm{d}, \mathrm{e}}$, Sonia Fraga ${ }^{\mathrm{d}, \mathrm{e}}$, Maria Joao Bessa ${ }^{\mathrm{d}, \mathrm{e}}$, Eduardo Pásaro ${ }^{\mathrm{a}}$, \\ João Paulo Teixeira ${ }^{\mathrm{d}, \mathrm{e}}$, Blanca Laffon ${ }^{\mathrm{a}, *}$ \\ a DICOMOSA Group, Department of Psychology, Area of Psychobiology, Universidade da Coruña, Edificio de Servicios Centrales de Investigación, Campus \\ Elviña s/n, A Coruña 15071, Spain \\ ${ }^{\mathrm{b}}$ Department of Cell and Molecular Biology, Universidade da Coruña, Facultad de Ciencias, Campus A Zapateira s/n, A Coruña 15071, Spain \\ c Division of Molecular Toxicology, Institute of Environmental Medicine, Karolinska Institutet, Stockholm 171 77, Sweden \\ d Department of Environmental Health, Portuguese National Institute of Health, Rua Alexandre Herculano, 321, Porto 4000-055, Portugal \\ e EPIUnit-Institute of Public Health, University of Porto, Rua das Taipas, 135, Porto 4050-600, Portugal
}

\section{A R T I C L E I N F O}

\section{Article history:}

Received 29 February 2016

Received in revised form 29 March 2016

Accepted 30 March 2016

\section{Keywords:}

Iron oxide nanoparticles

In vivo studies

In vitro studies

Epidemiological studies

Toxicity

\begin{abstract}
A B S T R A C T
Due to their unique physicochemical properties, including superparamagnetism, iron oxide nanoparticles (ION) have a number of interesting applications, especially in the biomedical field, that make them one of the most fascinating nanomaterials. They are used as contrast agents for magnetic resonance imaging, in targeted drug delivery, and for induced hyperthermia cancer treatments. Together with these valuable uses, concerns regarding the onset of unexpected adverse health effects following exposure have been also raised. Nevertheless, despite the numerous ION purposes being explored, currently available information on their potential toxicity is still scarce and controversial data have been reported. Although ION have traditionally been considered as biocompatible - mainly on the basis of viability tests results - influence of nanoparticle surface coating, size, or dose, and of other experimental factors such as treatment time or cell type, has been demonstrated to be important for ION in vitro toxicity manifestation. In vivo studies have shown distribution of ION to different tissues and organs, including brain after passing the blood-brain barrier; nevertheless results from acute toxicity, genotoxicity, immunotoxicity, neurotoxicity and reproductive toxicity investigations in different animal models do not provide a clear overview on ION safety yet, and epidemiological studies are almost inexistent. Much work has still to be done to fully understand how these nanomaterials interact with cellular systems and what, if any, potential adverse health consequences can derive from ION exposure.
\end{abstract}

(c) 2016 Elsevier GmbH. All rights reserved.

\section{Contents}

1. Introduction.

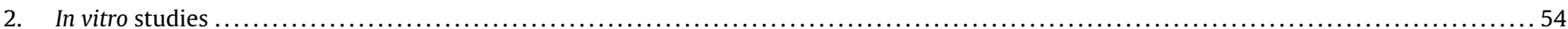

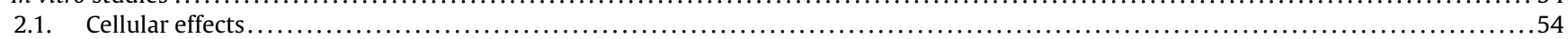

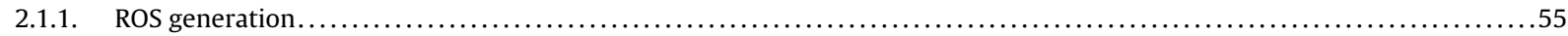

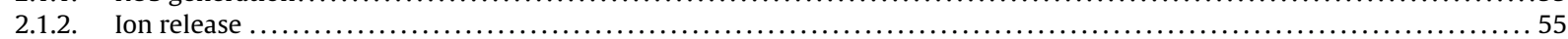

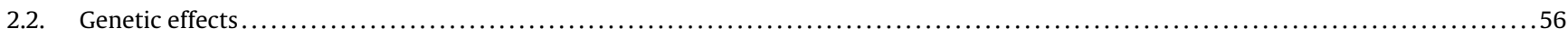

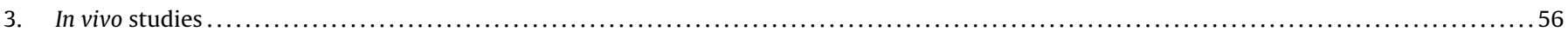

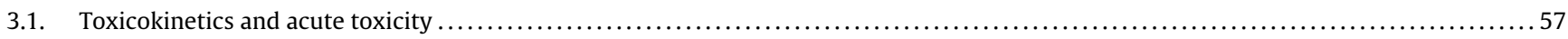

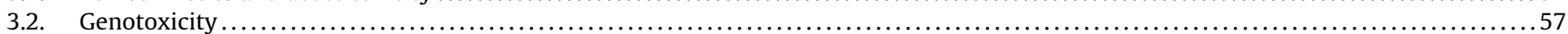

\footnotetext{
* Corresponding author.

E-mail address: blaffon@udc.es (B. Laffon).

1 These authors contributed equally to this work. 


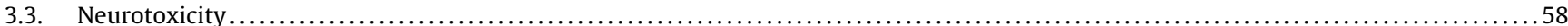

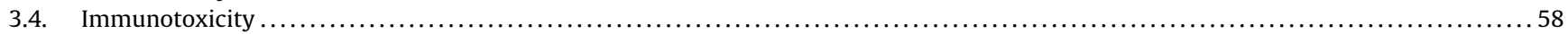

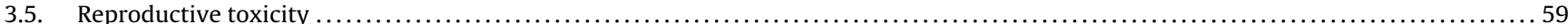

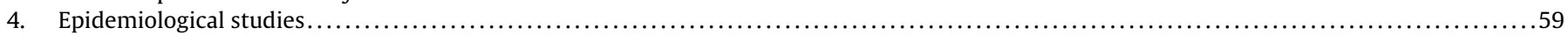

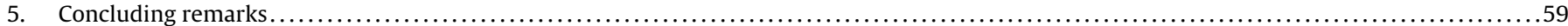

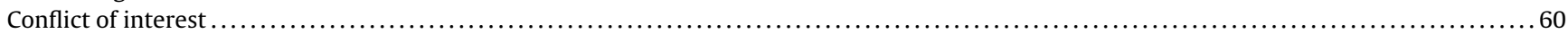

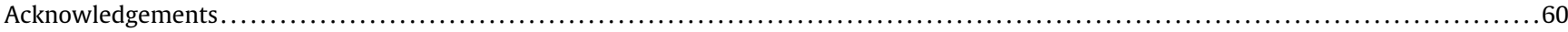

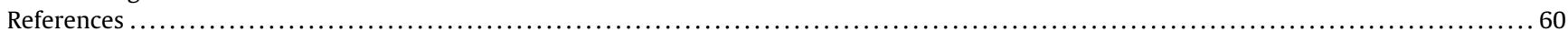

\section{Introduction}

Nanotechnology is rapidly expanding. With the increased applications of nanotechnology products, especially for biomedical purposes, concerns regarding the onset of unexpected adverse health effects following exposure have been also raised. Understanding of toxicological profiles of engineered nanomaterials is necessary in order to ensure that these materials are safe for use and are developed responsibly, with optimization of benefits and minimization of risks. However, development and production of engineered nanomaterials are increasing faster than generation of toxicological information. This lack of information on possible adverse effects of nanomaterials has been taken into consideration by many organizations worldwide such as the US Environmental Protection Agency (EPA), the World Health Organization (WHO), the US National Institute for Occupational Safety and Health (NIOSH), the European Commission (EC) and the Organization for Economic Co-operation and Development (OECD). Official documents have been prepared by these organizations addressing the need of dedicated research on appropriate methodological assays for assessing engineered nanomaterials toxicity [1]. Consequently, starting in the early 2000s, concerns about the potential human and environmental health effects of nanomaterials were being expressed by many scientists, regulators, and non-governmental agencies. Indeed, as a proof of the growing interest on this topic, the number of scientific articles published on 'nanotoxicity' or 'nanotoxicology' increased progressively in the last decade (around 1700 so far, according to PubMed database); before 2005 it was almost negligible.

Among engineered nanomaterials magnetic nanoparticles made of iron, cobalt, or nickel oxides - offer promising possibilities in biomedical field mainly due to their special physicochemical features, including their proven biocompatibility and their magnetic properties that allow them to be manipulated by an external magnetic field gradient [2]. Particularly, nanoparticles made of a ferroor ferromagnetic material, i.e., iron oxide nanoparticles (ION), can exhibit a unique form of magnetism called superparamagnetism, which appears when the ION size is below a critical value - depending on the material, but typically around $10-20 \mathrm{~nm}-$, and when the temperature is above the so-called blocking temperature [3]. This superparamagnetic behaviour is highly useful in biomedicine for a number of applications mainly related to diagnosis, tumour imaging, imaging of the central nervous system for neurovascular, neurooncological or neuroinflammatory processes, and drug delivery $[4,5]$. Indeed, clinical use of several ION as contrast agents for imaging were already approved by the US Food and Drug Administration since 1996 (US FDA) [6-8]. Therefore, due to the current and promising biomedical uses of ION involving the direct contact with different tissues and organs, studies addressing their potential toxicity are especially relevant.

ION are usually made of a crystalline core and a surface coating for stabilizing the core properties and optionally for preventing the aggregation. The crystalline core of ION, made of ferri- $\left(\mathrm{Fe}^{3+}\right)$ or ferro- $\left(\mathrm{Fe}^{2+}\right)$ magnetic material, is generally synthesized through protocols with controlled precipitation of iron oxides in organic solution [9], or in aqueous solution by adding a base [10]. Among the eight iron oxides known, magnetite $\left(\mathrm{Fe}_{3} \mathrm{O}_{4}\right)$, maghemite $(\gamma$ $\left.\mathrm{Fe}_{2} \mathrm{O}_{3}\right)$ and hematite $\left(\alpha-\mathrm{Fe}_{2} \mathrm{O}_{3}\right)$ are the most commonly used due to their polymorphism involving temperature-induced phase transition; they have unique biochemical, magnetic, catalytic, and other properties which provide suitability for specific technical and biomedical applications [9]. Surface of commercially available nanoparticles is normally modified by coating with different materials in order to stabilize them, modify their biodistribution, and enhance their biocompatibility. This coating is applied by adding a stabilizing coating material [e.g., citrate, dextran, carboxydextran, chitosan, pullulan, polyethylene glycol (PEG), polyvinyl alcohol (PVA), polyethylenimine (PEI), polyethylene oxide (PEO), polysaccharide, albumin, lipids, etc.] to monocrystalline (uniform ION with close particle size distribution) or polycrystalline (with significant size variance) ION [11]. Furthermore, particle coating may be further modified, especially in case of medical uses, with fluorescent dyes for imaging [12,13], targeting molecules [13,14], drugs [15] or nucleic acids [16,17]. This great variety of coatings leads to many diverse types of ION with different potential action mechanisms and toxic patterns.

ION have been reported in many studies to be highly biocompatible nanomaterials with none or low toxicity which do not pose a serious threat to the organism [18-21]. Despite being considered as generally safe, potential ION toxicity cannot be completely discarded since results from studies on this regard are often contradictory and ION effects at particular levels, such as genetic or carcinogenic, have been poorly addressed. Also, their effects on whole organisms and, specially, human health risks related to occupational and environmental exposure to ION have been scarcely evaluated. On this basis, and in order to improve the knowledge in this field, the aim of this review was to compile the in vitro, in vivo and epidemiological studies on ION toxicity published to date. Thus, the results and conclusions from the main ION toxicology studies were analysed, providing a general view of the current information on ION safety available as well as highlighting the main gaps of knowledge in the field that must be further addressed.

\section{In vitro studies}

\subsection{Cellular effects}

Most studies analysing ION toxicity are focused on cytotoxic effects of these nanoparticles on cell cultures. A number of different cell lines and testing conditions have been assessed reporting ION cellular effects at different levels, mainly decrease in viability, ROS production, and iron ion release, but also apoptosis induction, cell cycle alterations, cell membrane disruptions, cytoskeleton modifications, etc. An exhaustive revision of the former works can be found in some previous papers $[22,23]$. Since then, several studies published addressing the potential ION cytotoxicity show in general none or low cytotoxic effects of these nanoparticles. For instance, no adverse cellular effects were found in primary rat cerebellar cortex astrocytes treated with PEI-coated ION (magnetite) [24], in cultured rat astrocytes treated with 
citrate- or dimercaptosuccinate (DMSA)-coated ION (maghemite) $[25,26]$, in murine bone marrow cells treated with bare or citratemodified ION $\left(\mathrm{Fe}_{2} \mathrm{O}_{3}\right)$ [21], in human $\mathrm{T}$ lymphocytes exposed to polyacrylic acid (PAA)-coated or non-coated ION (magnetite) [27], in human mesenchymal stem cells treated with ferucarbotran (magnetite/maghemite-carboxydextran) [28], in human amniotic fluid cells (hAFC) [29] incubated with carboxydextrancoatednanomagnetite, in cultured primary rat cerebellar neurons treated with DMSA-coated ION (maghemite) [30], or, in general, after exposure of murine microglial cells to different ION [31-33].

Nevertheless, other in vitro studies have reported positive cytotoxicity outcomes after ION exposure. Szalay et al. [34] found that ION (magnetite) induced moderate time- and concentrationdependent decrease in viability of Vero cells after $24 \mathrm{~h}$ exposure, and low generation of cytotoxicity was observed in L-929 fibroblasts treated with ION modified with different functional groups [35-37]. Similarly, decreases in viability were found in human alveolar epithelial A549 cells treated with ION $\left(\mathrm{Fe}_{2} \mathrm{O}_{3}\right)$ [38], in cultured rat astrocytes exposed to aminosilane- or starch-coated ION (magnetite) at physiological temperatures $\left(34-40^{\circ} \mathrm{C}\right)$ [39], in human glioblastoma (T98G and U251MG) and urinary bladder carcinoma (ECV304) cell lines after treatment with rhamnose-coated ION (magnetite) [40] and in human neuronal (SHSY5Y) and glial (A172) cells exposed to oleic acid-coated or silica-coated magnetite nanoparticles [41].

On the basis of most of these studies, ION seem to be initially safe for biomedical use since their potential cytotoxic effects, if any, are usually slight or limited to specific conditions (e.g., highest doses and/or longest exposure times), and cytotoxicity is considered only as a decrease in cell viability. However, other reports have demonstrated that these nanoparticles can exert other drastic effects on the cell wellbeing (reviewed in Ref. [42]). Indeed, different cellular effects - mainly dependent on ION concentration, time of exposure, presence and type of coating, and cell type evaluated - have been reported after ION exposure in in vitro studies. Those effects include plasmatic membrane impairment [43,44], cell cycle alterations [45,46], cytoskeleton disruption [47], autophagy $[48,49]$, changes in mitochondrial membrane potential [50,51], and alterations in cell motility [52] and in cell integrity [53].

In summary, some authors have suggested that inconsistent results on ION cellular effects may be related to nanoparticle features, mainly size and surface coating [54,55]. Thus, Li et al. [56] carried out a comparative study measuring some cytotoxic effects, namely intracellular enzymatic activity and membrane disruption, in human cervical cancer (HeLa) cell line and immortalized normal human retinal pigment epithelial (RPE) cell line exposed to ION (magnetite). Results obtained showed that uncoated ION resulted toxic to both HeLa and RPE cells at a high concentration $(0.40 \mathrm{mg} / \mathrm{ml})$; however, at low concentrations, cytotoxicity was cell-type specific, being RPE cells more susceptible than HeLa cells. With a similar approach, Soenen et al. [57] tested four different ION types (dextran-coated Endorem, carboxydextran-coated Resovist, lipid-coated magnetoliposomes and citrate-coated very small iron oxide particles) on c17.2 neural progenitor cells, and different cytotoxic potential relating to the type of coating was also observed in this case. Thus, citrate-coated ION resulted the most toxic and lipid-coated ones were the less toxic. Moreover Rivet et al. [55] investigated the response of primary cortical neurons to aminosilane-, dextran- and polydimethylamine-coated ION (magnetite), and observed different effects depending on nanoparticle dose and coating. Furthermore, uncoated ION (magnetite) were found to be non-cytotoxic to human lymphoblastoid TK6 cells and primary human blood cells, while oleate-coated magnetite nanoparticles were cytotoxic in a dose-dependent manner [58]. Similarly, uncoated ION (magnetite) prevented - while PAA-coated ION prevented - apoptotic signalling and apoptosis in human neutrophils in vitro [59]. In another study, aminosilane-coated nanomagnetite was found to decrease viability of primary cortical cultured neurons, but in a diverse grade depending on whether ION were positively or negatively charged [60]. More recently, Schütz et al. [48] reported that the stress response of HT29 and Caco2 cells was cell- and nanoparticle-specific. However, other authors suggested that ION concentration may be an even more critical factor for cytotoxicity than surface modification or size [36,61].

As the ION-induced cytotoxic effects reported in the literature are frequently related to reactive oxygen species (ROS) generation and iron ion release, these specific outcomes are addressed separately in the following subsections.

\subsubsection{ROS generation}

A number of in vitro studies have associated cytotoxicity induced by ION with oxidative stress and ROS production [62-64]. Thus, an increased generation of ROS by ION exposure was previously observed in Chinese hamster ovary (CHO-K1) cells [65], murine macrophage J774 cells [66], different vascular endothelial cells [67,68], Chinese hamster lung cells [69], human lung A549 cells $[43,70]$, brain microglia cells [71], and glial T98G and U251MG and bladder ECV304 cells [40]. However, other studies reported negative results on ROS production after ION treatment [72,73]. Several authors have suggested that oxidative stress and ROS generation induced by ION can be associated with the presence and type of surface coating [65,72]. In any case, this presence of high intracellular ROS levels may $[63,68]$ or may be not $[43,70]$ associated with ION-induced cytotoxicity.

Since the brain is particularly vulnerable to ROS damage, a number of studies have evaluated oxidative stress consequences of treatment with different ION on cultured neural cells. Wu and Sun [45] found oxidative stress, decrease in neuron viability, and activation of JNK- and p53-mediated pathways to regulate the cell cycle and apoptosis in PC12 cells treated with $\mathrm{ION}\left(\mathrm{Fe}_{3} \mathrm{O}_{4}\right)$. Wang et al. [74] observed that treatment with ION $\left(\alpha-\right.$ and $\left.\gamma-\mathrm{Fe}_{2} \mathrm{O}_{3}\right)$ led to generation of ROS and nitric oxide, cell proliferation, and phagocytosis in mouse microglial Bv2 cells, and ROS formation was also found in human brain-derived endothelial cells (a model of the blood-brain tumour barrier) treated with oleic acid-and polyvinylamine-coated ION $\left(\mathrm{Fe}_{3} \mathrm{O}_{4}\right)$ [75]. Recently, Petters et al. [71] compared the effects of DMSA-coated ION $\left(\gamma-\mathrm{Fe}_{2} \mathrm{O}_{3}\right)$ exposure on different brain cells, namely, microglial cells, neurons and astrocytes. Results showed that ION treatment induced increases in iron content, ROS generation and cell toxicity in microglial cells but not in astrocytes and neurons. Similarly to these negative results in astrocytes and neuronal cells, Hohnholt et al. [76,77] reported neither substantial ROS production nor any alteration in the cellular thiol reduction potential after exposure of oligodendroglial OLN-93 cells to ION $\left(\gamma-\mathrm{Fe}_{2} \mathrm{O}_{3}\right)$.

\subsubsection{Ion release}

Due to iron capacity to switch between ferric $\left(\mathrm{Fe}^{3+}\right)$ and ferrous $\left(\mathrm{Fe}^{2+}\right)$ ionic forms by easily accepting and donating electrons (reduction-oxidation reactions), it plays a critical role in important organic metabolic pathways such as cytochrome P450 function, mitochondrial oxidative phosphorylation, oxygen transport, DNA synthesis, and for energy production [78]. Nevertheless, as excess of this metal can be very toxic, iron levels in the organism are strictly controlled. Free iron released from ION metabolisation can be incorporated to the normal cellular iron pool from the endocytic compartment [22]. Thus, ION exposure in a variety of cells caused elevated intracellular iron concentrations, dependent on the dose $[25,32,40,79]$. Therefore, the normal body capacity to manage iron should be taken into account when considering administration of high or frequently repeated doses of ION [20]. 
Apart from nanoparticle exposure characteristics, also cell features can influence ION effects since, depending on cell type, iron ions released from ION can be harmless for cells [25,32,79], induce cytotoxicity [80], or even be used by cells for their own metabolism, as it was observed for oligodendroglial OLN-93 cells [76,77]. A possible explanation is that, under normal conditions, iron released from ION can be accumulated in cells where it is stored as an iron-ferritin complex to annul the high toxicity associated with free iron $[80,81]$. Hence, this storage likely contributes to high cell resistance to iron toxicity and is especially relevant in the nervous tissue, since even the prolonged presence of large amounts of accumulated ION does not harm these cells. On this regard, a recent review on ION uptake and metabolism in brain astrocytes suggests that the efficient uptake of extracellular iron (liberated slowly from ION) by astrocytes, as well as their strong up-regulation of the synthesis of ferritin contribute to the high resistance of these cells to iron toxicity. So astrocytes deal well with an excess of iron and protect the brain against iron-mediated toxicity [81]. These results are supported by recent findings showing that astrocytes, and also neurons, are more resistant against acute ION toxicity, likely due to a slow transfer of internalized nanoparticles into the lysosomal compartment, required for iron ion release from ION [71]. However, under pathological conditions (such as cancer, atherosclerosis, hypertension or arthritis) iron may effectively be released from ferritin leading to increased oxidative damage and causing cellular toxicity $[82,83]$.

\subsection{Genetic effects}

A number of in vitro studies have evaluated the effects of ION exposure on genetic material, mainly by means of comet assay and micronucleus (MN) approach. Still, there is lack of consistence in ION genotoxicity results, even at similar doses. Thus, comet assay evaluation of murine L-929 fibroblasts treated with ION (magnetite) coated with (3-aminopropyl)trimethoxysilane (APTMS), tetraethyl orthosilicate (TEOS)-APTMS, or citrate showed a concentration-dependent increase in DNA damage regarding control cells [36]. Similar genotoxic effects were described after ION (magnetite) treatment in alveolar A549 and bronchial epithelial BEAS-2B cells [84], embryonic kidney HEK-293 cells and peripheral blood lymphocytes [85], and in skin epithelial A431 cells [86], and also in human lymphoblastoid TK6 cells and primary human leukocytes exposed to oleate-coated nanomagnetite [58]. Using the same methodology, Bhattacharya et al. [87] found DNA damage induction in human lung IMR-90 fibroblasts and human BEAS2B cells treated with nanohematite, and Rajiv et al. [44] observed DNA breaks and chromosome aberrations in human lymphocytes exposed to ION $\left(\mathrm{Fe}_{2} \mathrm{O}_{3}\right)$. Also MN production was observed in human lymphoblastoid MCL5 cells treated with dextran-coated maghemite nanoparticles for $24 \mathrm{~h}$ [88]. Similarly, positive response was observed in A549 cells treated with bare nanomagnetite both in the comet assay and MN test, but the damaging effect was reduced by simultaneous exposure to $N$-acetylcysteine or by pretreatment with butylated hydroxyanisole, both ROS scavengers [70]. However, it was recently reported that oxidative stress plays, at most, only a marginal role in genotoxicity induction (evaluated by comet assay) by surface-modified magnetite nanoparticles [89].

Still, studies showing negative results for ION genotoxicity are even more frequent. Karlsson et al. [38,90] observed no induction of primary DNA damage (comet assay) in A549 cells exposed to ION $\left(\mathrm{Fe}_{2} \mathrm{O}_{3}\right.$ and $\left.\mathrm{Fe}_{3} \mathrm{O}_{4}\right)$, but oxidative DNA damage was produced by magnetite nanoparticles. Also, MN frequency was not found to be altered in human lymphoblastoid cells after treatment with uncoated nanomaghemite or with nanomagnetite, both uncoated and dextran-coated [88]. Likewise, Guichard et al. [91] obtained neither increase in DNA damage, evaluated by comet assay, nor induction of $\mathrm{MN}$ formation using $\mathrm{Fe}_{2} \mathrm{O}_{3}$ (primarily maghemite) and magnetite nanoparticles to treat Syrian hamster embryo cells. Genotoxicity caused by exposure of Chinese hamster lung cells to glutamic acid-coated $\mathrm{Fe}_{2} \mathrm{O}_{3}$ nanoparticles was assessed by using the same tests and no significant positive response was obtained, although cell redox status was slightly disturbed [69]. Liu et al. [92] found no increase in the incidence of chromosome aberrations in Chinese hamster lung cells treated with ION $(10 \mathrm{~nm})$ with positively charged PEI surface or with neutral non-functional PEG-coated ION (10 and $30 \mathrm{~nm}$ ). Besides, normal human fibroblasts exposed to meso-2,3-dimercaptosuccinic acid (DMSA)-coated maghemite nanoparticles showed also no increases in DNA damage attributed in part to the inhibition of potential toxicity by the DMSA coating, which acts as a barrier avoiding direct contact between fibroblasts and the nanoparticle core [93]. DNA damage was neither observed after treatment of L-929 fibroblasts with bare or TEOS-coated ION (magnetite) [36] or in lymphoblastoid TK6 cells and primary human leukocytes treated with uncoated nanomagnetite [58]. More recently, Couto et al. [27] also demonstrated absence of ION effects on genetic material of human T-lymphocytes reporting no chromosome aberrations in cells treated with PAA-coated and non-coated nanomagnetite for $48 \mathrm{~h}$. In agreement with these studies, Paolini et al. [40] reported absence of genotoxic and carcinogenic effects of rhamnose-coated ION (magnetite) on mouse fibroblast Balb/c-3T3 cells. Furthermore, a number of studies evaluating the potential mutagenicity induced by different ION by means of Ames test, with or without metabolic activation, were also reported with negative results [34,94,95]. However, Gomaa et al. [85] described both positive and negative results in the Ames test for ION (magnetite) depending on the administered dose and the presence of metabolic activation. Supporting this observation, Liu et al. [92] concluded recently that ION mutagenicity could be dependent on nanoparticle size and surface coating after having found a positive mutagenic response (Ames test) in cells treated with PEG-coated ION (10 nm) but not in cells treated with PEI-coated ION $(10 \mathrm{~nm})$ or PEG-coated ION $(30 \mathrm{~nm})$.

\section{In vivo studies}

Since nanomaterial studies based on cell cultures are often inconsistent and might underestimate their effects, toxicity of nanomaterials needs to be examined in whole animal systems [96]. Besides, nanomaterial uptake and distribution in the body are complex processes that cannot be properly addressed in cultured cells, and in vitro particle size can change when used in vivo due to the additional deposition of salts, opsonization with plasma proteins, lipids or carbohydrates, depending on the surface charges of the coating molecules, or due to the clustering of nanoparticles to form conglomerates [5]. Thus, in vivo studies on nanomaterials toxicity are essential and have an obvious advantage over in vitro tests, providing actual information about overall effects on a living organism, including the final cell or tissue targets.

However, in vivo studies on ION toxicity are still scarce and also showed controversial results. Thus, negative or trivial toxicity results were reported for different ION in several organs of Wistar rats treated intravenously [97], intratracheally [34] or orally [98], in mice exposed orally [99] or subcutaneously [100], in growing chickens after oral administration [101], and in monkeys and dogs intravenously treated [95]. On the contrary, positive toxicity outcomes were observed in several rodent models exposed to ION by pulmonary $[64,102]$, intraperitoneal $[47,103,104]$ or intravenous [105] administration. 


\subsection{Toxicokinetics and acute toxicity}

It is generally well accepted that the toxicokinetics of metallic nanoparticles depends on the particle type, size, surface charge, surface coating, protein binding, exposure route, dose, and species [106]. Bourrinet et al. [95] investigated ION toxicokinetics in rats and monkeys intravenously treated with ferumoxtran-10. The highest ION uptake was obtained in spleen, followed by central lymph nodes, peripheral lymph nodes, liver, and bone marrow, with a general elimination half-life of about 8-10 days. Studies describing ION toxicokinetics in other in vivo models (usually rodents) are frequently accompanied by assessment of acute toxicity outcomes. Several of these works reported absence of toxicity after ION administration. Thus, different concentrations of magnetite-zinc oxide core-shell nanoparticles were injected subcutaneously, weekly for four weeks, to C57BL/6 mice to examine tissue distribution, excretion pattern and systemic toxicity [100]. No distribution was observed to brain, spleen, lung, kidney or liver, and neither changes in zinc concentrations in urine and faeces. Besides, absence of significant modifications in mortality, clinical observations, body weight, food intake, water consumption, urinalysis, haematology, serum biochemistry, or organ weights was reported. Just a dose-dependent increase in granulomatous inflammation was found at the injection site of treated animals, but no other histopathological lesion in any organ could be attributed to the nanoparticle exposure. Moreover, no systemic distribution of $\mathrm{Fe}_{2} \mathrm{O}_{3}$ nanoparticles or significant changes in toxicity parameters were observed in Sprague-Dawley rats orally administered, daily over a 13-week period [99]. Ansciaux et al. [107] functionalized several ultrasmall iron oxide particles with peptides that present an affinity for amyloid- $\beta$ peptide, for being used in early diagnosis of Alzheimer's disease. The particles coupled to peptide C-IPLPFYN-C demonstrated ability to cross the blood-brain barrier in mice without any facilitating strategy, and accumulated in brain $90 \mathrm{~min}$ after their intravenous injection. However, no toxic effects were observed after exposure and none of the derivatives tested was found in any organ one week after administration; elimination half-life was about $3 \mathrm{~h}$. Recently, Yang et al. [108] investigated the size-dependent in vivo kinetics, toxicity and gene expression changes caused by carboxyl-coated ION (magnetite, diameters 10 , 20,30 , and $40 \mathrm{~nm}$ ). They demonstrated that ION accumulated primarily in liver and spleen of Kunming mice on the first day post-intravenous injection, following a size-dependent pattern, with $10 \mathrm{~nm}$ nanoparticles showing the highest uptake by liver and $40 \mathrm{~nm}$ nanoparticles the highest uptake by spleen. Moreover, $10 \mathrm{~nm}$ ION were cleared faster from liver and kidneys, but entered more readily brain and uterus, whereas $40 \mathrm{~nm}$ ION accumulated more readily but were easily eliminated in spleen. No apparent signs of acute toxicity were observed, but ION exposure was able to change the expression level of sensitive genes related to oxidative stress, iron transport, metabolic processes, and apoptosis, among others. Likewise, Chamorro et al. [101] reported accumulation of nanoparticles in liver, spleen, or duodenum of growing chickens chronically exposed to low doses of ION $\left(\gamma-\mathrm{Fe}_{2} \mathrm{O}_{3}\right)$ by oral route; faeces were the main excretion route. It was also noticed that iron ions were released as a consequence of the partial ION transformation by the acid gastric environment, but they were absorbed enhancing the ferric over ferrous pathway. Besides, no mortality or adverse signs or symptoms were observed. Lack of toxic effects was also reported in rats treated with ION (II, III) since no histopathological alterations were found in these animals after a single intratracheal instillation [34].

Nevertheless, opposite to all these studies, a number of works have described acute animal toxicity after ION exposure. Kumari et al. [109] reported that Wistar rats exposed orally to ION $\left(\mathrm{Fe}_{2} \mathrm{O}_{3}\right)$ for 28 days showed distribution of the nanoparticles to several organs, including brain, and toxic signs such as dullness, irritation and moribund conditions, but no mortality. Increased iron content, changes in homeostasis of trace elements and immunological alterations were observed in several organs of mice that received a single ION (magnetite) dose injected through the tail vein [110]. Nanoparticles were primarily distributed to liver at 1 week postinjection, and iron levels increased remarkably in thymus, lung, heart, liver, and spleen at 4 weeks post-injection; at 13 weeks postinjection, iron levels were the highest in the spleen. Furthermore, Kwon et al. [111] studied the biodistribution and biomodification of ION $\left(\mathrm{Fe}_{3} \mathrm{O}_{4}\right.$ and $\left.\alpha-\mathrm{Fe}_{2} \mathrm{O}_{3}\right)$ in Daphnia magna and found a number of morphological changes (e.g., irregular shaped microvilli, epithelial cell protrusion, and dilatation of cytoplasmic inclusion) in the gut tissues of these crustaceans, along with bacterial colonization of the gut lumen, after ION exposure, even without penetrating these tissues. The authors suggested that these effects may be due to ION biomodifications probably involving oxidative dissolution of $\mathrm{Fe}_{3} \mathrm{O}_{4}$ followed by a rapid precipitation of ferric oxide or hydroxide.

Two recent independent studies reported also relevant toxic effects in mouse and rat lungs after ION administration. Radu Balas et al. [112] evaluated biochemical and histopathological changes in CD-1 mice exposed to ION coated with phospholipid-based polymeric micelles by intravenous injection. Alterations in activity of several enzymes - including catalase, glutathione reductase, lactate dehydrogenase, superoxide dismutase and glutathione peroxidase - were found in treated animals regarding the controls. Furthermore, histopathological modifications, dose-dependent decrease of the mouse lung capacity and major changes in the expression of apoptosis markers were also highlighted. And Sadeghi et al. [64] evaluated the effects of ION on lung tissue of adult male Wistar rats after pulmonary inhalation. Administered nanoparticles penetrated the circulation, rapidly reached liver, and caused serious inflammation in lung and liver tissues. Results also showed significant increase of free radicals and reduction of glutathione in lung tissue, together with pulmonary emphysema and interstitial hyperemia in lungs, and hepatic injuries that led to release of hepatic enzymes to the blood serum.

In addition, Baratli et al. [113] examined the effects of ION $\left(\mathrm{Fe}_{3} \mathrm{O}_{4}\right)$ on mitochondrial respiratory chain complex activities and mitochondrial coupling in young (3 months) and middle-aged (18 months) rat livers, finding interesting differences depending on animal age. In young individuals, ION exposure did not alter mitochondrial function; however, nanoparticles dose-dependently impaired all complexes of the mitochondrial respiratory chain in middle-aged rat liver. And Gustafsson et al. [114] investigated the inflammatory and immunological responses to ION in healthy nonsensitized mice, and in sensitized mice with an established allergic airway disease. Animals were exposed to hematite nanoparticles for up to 7 days and different toxic responses - including alterations in white blood cell levels and reduction of alveolar space were observed highly dependent on the initial mouse respiratory features.

Taking the results from all these studies together, it seems that differences found in the literature regarding ION toxicokinetics and associated toxicity are related to nanoparticle size [108], crystalline phase and dissolution rate [111], administered dose [101], and age [113] or preexistent pathological state [114] of the study animals.

\subsection{Genotoxicity}

In vivo studies addressing the potential genotoxic effects of ION are scarce in the literature, and results obtained from them are not conclusive yet. Different types of DNA alterations were found in a number of animal studies after ION exposure. Thus, DNA-protein crosslinks and oxidative DNA damage (8-hydroxydeoxyguanosine) were observed in hepatic and renal tissues of 
Kunming mice treated daily for 1 week with magnetite nanoparticles via intraperitoneal injection [103]. An increase in MN frequency was also detected in bone marrow cells of mice intraperitoneally exposed to magnetite nanoparticles [104], or after intravenous administration of polyaspartic acid-coated ION (magnetite) [105]. Totsuka et al. [115] examined genotoxic effects of magnetite nanoparticles in mice intratracheally instilled, obtaining significant increases in DNA adduct levels, oxidative stress and DNA breaks in treated animals as compared with controls. In addition, inflammatory cell infiltration and focal granulomatous formations were also observed in lungs of exposed mice, suggesting that an inflammatory response might be involved in genotoxicity induced by ION in mice lungs [116]. Recently, Al Faraj et al. [102] performed a longitudinal study on Balb/c mice intrapulmonary administered ION (PEG-coated magnetite modified with negative [carboxyl] or positive [amine] terminal) acutely and sub-acutely. Accumulation of ION was detected in the liver after high-dose administration. Further, a significant increase in lipid peroxidation, DNA damage and gene expression of CCL-17 and IL-10 biomarkers was observed in both acute and sub-acute sets. The effects observed resulted surface coating-dependent, showing ION with carboxyl terminal a slightly prominent effect compared to the amine modification.

Despite these works, several in vivo studies reported negative results on genotoxic effects after ION exposure. Estevanato et al. [117] evaluated genotoxic effects of maghemite nanoparticles encapsulated within albumin-based nanospheres on female Swiss mice intraperitoneally injected by performing MN test systematically from $30 \mathrm{~min}$ until 30 days after injection, and no evidence of MN production was found in any case. Also no increase in MN frequency was observed in bone marrow cells from Kunming mice exposed by abdominal injection to magnetite nanoparticles either naked [118] or combined with daunorubicin [47]. Similarly, single and repeated intravenous (bolus) administration of ferumoxtran10 (an ultrasmall superparamagnetic ION contrast agent) did not produce increase of MN frequency in mice bone marrow after 24 or $48 \mathrm{~h}$ of exposure [95]. In the same study, genotoxicity was additionally measured by assessing DNA repair as unscheduled DNA synthesis (UDS) in primary hepatocyte cultures from treated rats, but negative results were obtained also in this case. Moreover, Liu et al. [92] found negative genotoxic response, evaluated by means of MN test, in male NIH mice intraperitoneally exposed to PEG- and PEI-coated ION. Besides, $\mathrm{Fe}_{2} \mathrm{O}_{3}$ (primarily maghemite) nanoparticles orally administered in a single dose to Wistar rats were easily able to pass across the intestinal barrier and, even though they were mainly accumulated in liver, spleen, kidney, heart and bone marrow, they did not cause DNA damage (according comet assay results) and MN production in peripheral leukocytes or chromosome aberrations in bone marrow cells [98].

Together with the high variability in ION type and dose tested, experimental design may also help explain the non-concordant results obtained from genotoxicity assessment of these nanoparticles. Hence, some authors highlighted the need of carrying out a range of genotoxicity assays in the same study in order to cover all the potential forms of DNA damage and accordingly provide proper conclusions on the genotoxic potential of nanomaterials $[119,120]$. Furthermore, possible interference of nanoparticles with standard genotoxicity methodologies is usually not considered in these studies and it should be, since interference has been previously demonstrated to be likely present, altering the obtained results $[121,122]$.

\subsection{Neurotoxicity}

ION have been shown to display the ability to cross the bloodbrain barrier after oral [123], inhalatory [111], and intraperitoneal [124] administration, and to directly reach the brain through the olfactory nerve after intranasal installation [125]. This ability makes them especially eligible for medical purposes on nervous system, such as drug delivery and imaging diagnostics, but also potentially harmful for this system. Hence, a special attention must be payed to the nervous tissue physiology and behavioural outcomes in animal studies. Nevertheless, unlike the considerable amount of studies addressing in vitro effects of ION on neural cells, the number of in vivo studies on potential neurotoxicity of these nanoparticles is quite restricted.

Most of the in vivo studies on ION neurotoxicity employed rats as experimental model. Hence, Kumari et al. [109] observed dullness and irritation in Wistar rats after 28 days of oral daily exposure to ION $\left(\mathrm{Fe}_{2} \mathrm{O}_{3}\right)$. Moreover, a significant dose-dependent inhibition of total, $\mathrm{Na}^{+}-\mathrm{K}^{+}, \mathrm{Mg}^{2+}$ and $\mathrm{Ca}^{2+}$-ATPases in brain, as well as acetylcholinesterase in brain and red blood cells, were found in exposed animals, suggesting that ION exposure may affect synaptic transmission and nerve conduction. Similarly, Bourrinet et al. [95] observed different physiological responses, including signs of polypnea, exophthalmos and mydriasis in this species after intravenous treatment of ION (ferumoxtran-10), although no neurobehavioural, neurovegetative, or psychotropic effects were detected. More recently, Kim et al. [126] treated Sprague-Dawley rats with different ION (DMSA-coated maghemite, and DMSA, PEG- and PEG-Au-coated magnetite) by intraneural injection (sciatic nerve); ION caused immune cell infiltration, neural inflammation and apoptosis, and induced neural antioxidant response. The same year, Wu et al. [127] detected a regional distribution of ION (magnetite) in brain of rats intranasally instilled for seven days. ION induced oxidative damage in striatum but not in hippocampus, despite the presence of nanoparticles in both regions resulted particularly high.

Agreeing with these studies on rats, neurotoxicity of ION has been also reported in mice and fish. In mice, intranasal administration of $\mathrm{Fe}_{2} \mathrm{O}_{3}$ nanoparticles induced pathological alterations in olfactory bulb, hippocampus and striatum; microglial proliferation, activation and recruitment were also observed in these areas, especially in the olfactory bulb [74]. In addition, mice treated with magnetite nanoparticles by intragastric administration were reported to show less activity and a slight loss of appetite [123]. In fish, dextran-coated $\mathrm{Fe}_{3} \mathrm{O}_{4}$ nanoparticles intraperitoneally administered to adult zebrafish were found to accumulate in brain inducing apoptosis and inhibition of acetylcholinesterase in this tissue. Moreover, although no alterations in the expression of genes associated with inflammation were observed, increased levels of ferric iron and enhanced mRNA levels of caspase-8, caspase- 9 and transcriptional factor AP-1 in brain of treated animals were also detected [129].

\subsection{Immunotoxicity}

Immunotoxic effects related to ION exposure were also reported some recent in vivo studies. Park et al. [130] investigated the tissue distribution and immunotoxicity of ION $\left(\mathrm{Fe}_{2} \mathrm{O}_{3}\right)$ in sixweek-old male IRC mice after intravenous injection. Increased iron levels regarding the control were found in all tissues evaluated, notable in liver, spleen and thymus, and also alterations in the immune system were observed in treated animals. Those included increased levels of white blood cells and neutrophils, interleukin (IL)-8 secretion and lactate dehydrogenase release. Likewise, systemic administration of dextran-stabilized ION also resulted in enhanced proliferation of mitogen-stimulated spleen-derived lymphocytes and secretion of IL- $1 \beta$ in male Wistar rats after 7 days of intravenous administration [131]. Sadeghi et al. [64] observed serious inflammation in lungs and liver of Wistar rats treated with ION $\left(\mathrm{Fe}_{2} \mathrm{O}_{3}\right)$ by pulmonary administration as well as presence of neutrophils, lymphocytes and eosinophils in the lung tissue. 
Similarly, Gustafsson et al. [114] observed an immunological response in mice exposed to ION (hematite). They described increased levels of neutrophils, eosinophils, and lymphocytes in the airways of healthy mice on days 1 and 2 post-exposure, but decrease of lymphocytes in sensitized (with an established allergic airway disease) mice. Opposite to these results, Wang et al. [128] found no significant differences in splenocyte proliferation or cytokine release in mice fed with magnetite nanoparticles. However, despite proportions of T-lymphocyte subsets were not altered after low ION exposures, CD3(+)CD4(+) and CD3(+)CD8(+) T-lymphocyte subsets were higher in animals exposed to medium and high ION doses that in the control group. Finally, Park et al. [110] found that magnetite nanoparticles intravenously administered to mice can disturb homeostasis of the immune regulation. Particularly, after 13 weeks post-injection, they observed increased percentages of neutrophils and eosinophils, enhanced release of lactate dehydrogenase, and elevated secretion of IL-8 and IL-6 in the blood of treated animals. Furthermore, expression of antigen presentation related-proteins and maturation of dendritic cells resulted inhibited after ION exposure whereas expression of several chemokines was enhanced in splenocytes.

\subsection{Reproductive toxicity}

Similar to the reports on ION neurotoxicity or immunotoxicity, the number of studies addressing reproductive toxicity of ION is scarce. Initially, ION were considered to show low developmental toxicity or teratogenic effects after having exposed Xenopus laevis embryos (Frog Embryo Teratogenesis Assay Xenopus, FETAX assay) to ION $\left(\mathrm{Fe}_{2} \mathrm{O}_{3}\right)$ for $48 \mathrm{~h}$ and observing no mortality or significant malformation; slight harmful effects, namely variations in total body length and snout vent length, were only noted at the highest concentration tested [132]. The same year, Noori et al. [133] evaluated ION effects on reproduction and offspring of mice treated with DMSA-coated magnetite nanoparticles. Even though no adverse effects on gestation and foetal growth were observed, a significant decrease in the offspring growth and maturation after birth and about 70\% death before reaching puberty were reported. Besides, male offspring showed decrease in the levels of spermatogonia, spermatocytes, spermatids and mature sperms, suggesting that embryo and foetal mouse development might be disrupted by placenta and foetus exposure to ION. Agreeing with these results, a later study on zebrafish (Danio rerio) showed that uncoated ION $\left(\alpha-\mathrm{Fe}_{2} \mathrm{O}_{3}\right)$ induced developmental toxicity in early life stages of this species, including mortality, hatching delay, and embryonic malformation [134]. And also $\mathrm{Fe}_{2} \mathrm{O}_{3}$ nanoparticles (primarily maghemite) were found to induce cytotoxicity and ROS production in Syrian hamster embryo cells exposed for $72 \mathrm{~h}$ [91]. However, Piccinetti et al. [135] recently observed that silica-coated magnetite nanoparticles do not induce any toxicity in zebrafish larvae exposed through food for up to 15 days. In this case, nanoparticles were excreted through faeces, and they did not activate detoxification processes or promote tissue/cell injury in larvae or adult individuals.

ION effects on fertility, reproductive performance, embryotoxicity, foetotoxicity, and teratogenicity were also evaluated in rats and rabbits exposed to ferumoxtran-10 [95]. Although no effects were generally observed on fertility or early embryonic development, mildly maternal toxicity and major foetal skeletal malformations were described in both species. Recently, developmental toxicity and biodistribution of a single dose versus multiple doses of ION with positive or negative surface charges (PEI-coated $\mathrm{Fe}_{2} \mathrm{O}_{3}$ or PAA-coated $\mathrm{Fe}_{2} \mathrm{O}_{3}$, respectively) were also investigated in vivo in pregnant CD-1 mice [136]. In this case, multiple doses of positively-charged nanoparticles given over several days resulted in significantly increased foetal deaths and accumulation of iron in the foetal liver and placenta. The same authors also evaluated the effects of prenatal exposure to these ION on mice during critical stages of organogenesis [137]. A low dose of ION did not induce toxicity, but foetal losses and morphological alterations of the uteri and testes of surviving offspring were observed after high ION dose exposure. Furthermore, the effects at short- or long-term varied depending on the type of ION employed.

\section{Epidemiological studies}

Epidemiological studies in the nanotoxicology field are very scarce. A limited number of nanomaterials, including titanium dioxide $\left(\mathrm{TiO}_{2}\right)$ nanoparticles, carbon nanotubes (CNT) or incidental ultrafine nanoparticles, have been evaluated so far to determine the health risks associated with their occupational exposure [138]. Proper population studies on environmental nanomaterial exposure are even more limited, almost inexistent. This significant lack of studies is likely related to the difficulty of characterising the exposure patterns. For instance, the nanoparticle component of the environmental air particulate pollution has not been specifically measured ever mainly because it is not possible to separate nanoparticle related effects from the effects of larger particulates that were omnipresent [139].

In this regard, field studies on the exposure characteristics of manufactured nanoparticles are relevant, but they are also limited thus far. In the case of ION, and despite the great relevance of testing the potential harmful effects of these particular nanoparticles on human health, to date just two recent studies have addressed this issue. Xing et al. [140] studied the exposure characteristics (particle nature, metric-dependent concentration and particle size) of airborne ION generated by the manufacturing processes of $\mathrm{Fe}_{2} \mathrm{O}_{3}$ nanomaterials in a factory in Zhejiang province (East China). In this study, relevant baseline data on the characteristics of ION exposure which could be used for further epidemiological studies were established. Thus, they observed that nanoparticle generation ability related to the different working activities (powder screening, material feeding and packaging) varied depending on their nature and that the particle concentration exhibited periodicity and activity relevance. Although no potential adverse health outcomes associated with ION exposure were addressed in this study, its findings highlighted the relevance of evaluating the potential health risks related to ION in workplaces where exposure to these nanoparticles is especially noticeable. Additionally, Pelclova et al. [141] analysed different oxidative stress biomarkers in exhaled breath condensate (EBC) and urine samples of 14 workers occupationally exposed to iron oxide aerosol (with more than $80 \%$ of particles smaller than $100 \mathrm{~nm}$ in diameter) during iron oxide pigment production for an average of $10 \pm 4$ years, and 14 matched controls. Almost all the oxidative stress biomarkers evaluated, including markers of lipid, nucleic acid and protein oxidation, resulted increased in $\mathrm{EBC}$ of workers regarding the control individuals. No differences in oxidative markers of both groups were found in urine samples. These results emphasize the necessity to periodically monitor for potential adverse health effects all ION exposed employees, including research workers who are directly exposed by handling these nanoparticles in the lab.

\section{Concluding remarks}

Due to their unique physicochemical properties, ION have a number of interesting current and potential future applications, especially in the biomedical field, that make them one of the most fascinating nanomaterials. Among other uses, they are currently employed in cell labelling, drug targeting, gene delivery, biosensors, hyperthermia therapy, and diagnostics, and they have promising future uses in therapies against cancer and other diseases. However, 
all these medical applications require internalization of ION for efficient diagnosis or treatment, leading to potential risks associated with exposure. As these applications are increasing in number and in benefits, there is an imperative need to comprehensively investigate and elucidate the biological undesirable consequences of exposure to these nanomaterials. Still, despite the numerous ION purposes being explored, insufficient and/or controversial information is available on their potential toxicity.

This paper revised the toxic effects of ION reported so far by different in vitro, in vivo and epidemiological studies. The analysis of all data collected highlights the lack of consensus in establishing the toxicity mechanism associated with ION exposure, mainly due to the high variability of particles present among the different studies. The presence [48], chemical composition [65], and charge [60] of surface coating seem to be critical factors for ION toxicity; usually bare nanoparticles are more toxic than the coated ones. But experimental conditions, such as cell/tissue type, concentration, exposure time, administration pathway and presence of protein corona, can also influence toxicity results. Special attention must be paid to the technical procedures employed for toxicity evaluation, since ION have been recently proven to interfere with the approaches commonly used for cytotoxicity $[41,58]$ and genotoxicity $[121,122]$ evaluation, leading to obtain false positive results.

Together with the low number of studies published, especially those performed in whole organisms, there is indeed a marked difficulty to set up comparisons and establish a toxicity pattern for ION mainly because of the different nanoparticles tested, but also to the lack of methodological standardization. Due to the variety of mechanisms that could lead to nanomaterial induced cell toxicity, a battery of harmonized testing systems is required to establish the presumptive toxic potential of ION at different levels. Moreover, in order to make results obtained in these investigations on ION with different coatings and characteristics comparable, the use of standardized methods, including proper testing of potential interferences with standard protocols, is highly desirable in each case.

In summary, ION toxicity, although suspected to be low, cannot be properly established yet since results from in vitro studies are often contradictory, in vivo studies are scarce, and human epidemiological studies are almost inexistent. Hence, in view of the extremely useful present and promising future applications of ION, especially those related to biomedical purposes which involve their direct introduction in the human body, the interactions of these nanomaterials with cellular systems, as well as the potential adverse health consequences of ION exposure, require to be fully understood, and much work has still to be done in this field.

\section{Conflict of interest}

The authors did not report any conflict of interest.

\section{Acknowledgements}

This work was supported by Xunta de Galicia (EM 2012/079), the project NanoToxClass (ERA ERASIINN/001/2013), and by TD1204 MODENA COST Action.

\section{References}

[1] R. Colognato, M.V.D.Z. Park, P. Wick, W.H. De Jong, Interactions with the human body, in: B. Fadeel, A. Pietroiusti, A.A. Shvedova (Eds.), Adverse Effects of Engineered Nanomaterials-Exposure, Toxicology, and Impact on Human Health, 1st edition, Elsevier, 2012, pp. 3-24.

[2] A.K. Gupta, M. Gupta, Synthesis and surface engineering of iron oxide nanoparticles for biomedical applications, Biomaterials 26 (2005) 3995-4021.

[3] M. Lu, M.H. Cohen, D. Rieves, R. Pazdur, FDA report: ferumoxytol for intravenous iron therapy in adult patients with chronic kidney disease, Am. J. Hematol. 85 (2010) 315-319.
[4] D.L. Huber, Synthesis, properties, and applications of iron nanoparticles, Small 1 (2005) 482-501.

[5] H. Ittrich, K. Peldschus, N. Raabe, M. Kaul, G. Adam, Superparamagnetic iron oxide nanoparticles in biomedicine: applications and developments in diagnostics and therapy, Rofo 185 (2013) 1149-1166.

[6] C.W. Lu, Y. Hung, J.K. Hsiao, M. Yao, T.H. Chung, Y.S. Lin, S.H. Wu, S.C. Hsu, H.M. Liu, C.Y. Mou, C.S. Yang, D.M. Huang, Y.C. Chen, Bifunctional magnetic silica nanoparticles for highly efficient human stem cell labeling, Nano Lett. 7 (2007) 149-154.

[7] P. Reimer, T. Balzer, Ferucarbotran (Resovist): a new clinically approved RES-specific contrast agent for contrast-enhanced MRI of the liver: properties, clinical development, and applications, Eur. Radiol. 13 (2003) 1266-1276.

[8] H.S. Sharma, P.K. Menon, J.V. Lafuente, Z.P. Aguilar, Y.A. Wang, D.F. Muresanu, H. Mossler, R. Patnaik, A. Sharma, The role of functionalized magnetic iron oxide nanoparticles in the central nervous system injury and repair: new potentials for neuroprotection with Cerebrolysin therapy, J. Nanosci. Nanotechnol. 14 (2014) 577-595.

[9] H.Y. Wu, M.C. Chung, C.C. Wang, C.H. Huang, H.J. Liang, T.R. Jan, Iron oxide nanoparticles suppress the production of IL-1beta via the secretory lysosomal pathway in murine microglial cells, Part. Fibre Toxicol. 10 (2013) 46.

[10] M. Mohapatra, S. Anand, Synthesis and applications of nano-structured iron oxides/hydroxides-a review, Int. J. Eng. Sci. Technol. 2 (2010) 127-146.

[11] K. Turcheniuk, A.V. Tarasevych, V.P. Kukhar, R. Boukherroub, S. Szunerits, Recent advances in surface chemistry strategies for the fabrication of functional iron oxide based magnetic nanoparticles, Nanoscale 5 (2013) 10729-10752.

[12] F. Bertorelle, C. Wilhelm, J. Roger, F. Gazeau, C. Menager, V. Cabuil, Fluorescence-modified superparamagnetic nanoparticles: intracellular uptake and use in cellular imaging, Langmuir 22 (2006) 5385-5391.

[13] F. Yan, Y. Wang, S. He, S. Ku, W. Gu, L. Ye, Transferrin-conjugated, fluorescein-loaded magnetic nanoparticles for targeted delivery across the blood-brain barrier, J. Mater. Sci. Mater. Med. 24 (2013) 2371-2379.

[14] L. Agemy, D. Friedmann-Morvinski, V.R. Kotamraju, L. Roth, K.N. Sugahara, O.M. Girard, R.F. Mattrey, I.M. Verma, E. Ruoslahti, Targeted nanoparticle enhanced proapoptotic peptide as potential therapy for glioblastoma, Proc. Natl. Acad. Sci. U. S. A. 108 (2011) 17450-17455.

[15] E.E. Hassan, J.M. Gallo, Targeting anticancer drugs to the brain. I: enhanced brain delivery of oxantrazole following administration in magnetic cationic microspheres, J. Drug Target. 1 (1993) 7-14.

[16] J.T. Jenkins, D.L. Halaney, K.V. Sokolov, L.L. Ma, H.J. Shipley, S. Mahajan, C.L. Louden, R. Asmis, T.E. Milner, K.P. Johnston, M.D. Feldman, Excretion and toxicity of gold-iron nanoparticles, Nanomedicine 9 (2011) 356-365.

[17] M. Kumar, M. Yigit, G. Dai, A. Moore, Z. Medarova, Image-guided breast tumor therapy using a small interfering RNA nanodrug, Cancer Res. 70 (2010) 7553-7561.

[18] S.M. Hussain, K.L. Hess, J.M. Gearhart, K.T. Geiss, J.J. Schlager, In vitro toxicity of nanoparticles in BRL 3A rat liver cells, Toxicol. In Vitro 19 (2005) 975-983.

[19] H.A. Jeng, J. Swanson, Toxicity of metal oxide nanoparticles in mammalian cells, J. Environ. Sci. Health A Tox. Hazard. Subst. Environ. Eng. 41 (2006) 2699-2711.

[20] A. Kunzmann, B. Andersson, C. Vogt, N. Feliu, F. Ye, S. Gabrielsson, M.S Toprak, T. Buerki-Thurnherr, S. Laurent, M. Vahter, H. Krug, M. Muhammed, A. Scheynius, B. Fadeel, Efficient internalization of silica-coated iron oxide nanoparticles of different sizes by primary human macrophages and dendritic cells, Toxicol. Appl. Pharmacol. 253 (2011) 81-93.

[21] S.Y. Paik, J.S. Kim, S.J. Shin, S. Ko, Characterization quantification, and determination of the toxicity of iron oxide nanoparticles to the bone marrow cells, Int. J. Mol. Sci. 16 (2015) 22243-22257.

[22] S.J. Soenen, M. De Cuyper, Assessing iron oxide nanoparticle toxicity in vitro: current status and future prospects, Nanomedicine (Lond.) 5 (2010) 1261-1275.

[23] W.H. Suh, K.S. Suslick, G.D. Stucky, Y.H. Suh, Nanotechnology, nanotoxicology, and neuroscience, Prog. Neurobiol. 87 (2009) 133-170.

[24] H.H. Yiu, M.R. Pickard, C.I. Olariu, S.R. Williams, D.M. Chari, M.J. Rosseinsky, $\mathrm{Fe}_{3} \mathrm{O}_{4}$-PEI-RITC magnetic nanoparticles with imaging and gene transfer capability: development of a tool for neural cell transplantation therapies, Pharm. Res. 29 (2012) 1328-1343.

[25] M. Geppert, M.C. Hohnholt, K. Thiel, S. Nurnberger, I. Grunwald, K. Rezwan, R. Dringen, Uptake of dimercaptosuccinate-coated magnetic iron oxide nanoparticles by cultured brain astrocytes, Nanotechnology 22 (2011) 145101.

[26] M. Geppert, M.C. Hohnholt, S. Nurnberger, R. Dringen, Ferritin up-regulation and transient ROS production in cultured brain astrocytes after loading with iron oxide nanoparticles, Acta Biomater. 8 (2012) 3832-3839.

[27] D. Couto, R. Sousa, L. Andrade, M. Leander, M.A. Lopez-Quintela, J. Rivas, P. Freitas, M. Lima, G. Porto, B. Porto, F. Carvalho, E. Fernandes, Polyacrylic acid coated and non-coated iron oxide nanoparticles are not genotoxic to human T lymphocytes, Toxicol. Lett. 234 (2015) 67-73.

[28] C.Y. Yang, J.K. Hsiao, M.F. Tai, S.T. Chen, H.Y. Cheng, J.L. Wang, H.M. Liu, Direct labeling of hMSC with SPIO: the long-term influence on toxicity, chondrogenic differentiation capacity, and intracellular distribution, Mol. Imaging Biol. 13 (2011) 443-451.

[29] P. Bigini, V. Diana, S. Barbera, E. Fumagalli, E. Micotti, L. Sitia, A. Paladini, C. Bisighini, L. De Grada, L. Coloca, L. Colombo, P. Manca, P. Bossolasco, F. 
Malvestiti, F. Fiordaliso, G. Forloni, M. Morbidelli, M. Salmona, D. Giardino, T. Mennini, D. Moscatelli, V. Silani, L. Cova, Longitudinal tracking of human fetal cells labeled with super paramagnetic iron oxide nanoparticles in the brain of mice with motor neuron disease, PLoS One 7 (2012) e32326.

[30] C. Petters, R. Dringen, Accumulation of iron oxide nanoparticles by cultured primary neurons, Neurochem. Int. 81 (2015) 1-9.

[31] H.B. Na, G. Palui, J.T. Rosenberg, X. Ji, S.C. Grant, H. Mattoussi, Multidentate catechol-based polyethylene glycol oligomers provide enhanced stability and biocompatibility to iron oxide nanoparticles, ACS Nano 6 (2012) 389-399.

[32] J.T. Rosenberg, A. Sachi-Kocher, M.W. Davidson, S.C. Grant, Intracellular SPIO labeling of microglia: high field considerations and limitations for MR microscopy, Contrast Media Mol. Imaging 7 (2012) 121-129.

[33] J. Wu, T. Ding, J. Sun, Neurotoxic potential of iron oxide nanoparticles in the rat brain striatum and hippocampus, Neurotoxicology 34 (2013) 243-253.

[34] B. Szalay, E. Tatrai, G. Nyiro, T. Vezer, G. Dura, Potential toxic effects of iron oxide nanoparticles in in vivo and in vitro experiments, J. Appl. Toxicol. 32 (2012) 446-453

[35] M. Mahmoudi, A. Simchi, A.S. Milani, P. Stroeve, Cell toxicity of superparamagnetic iron oxide nanoparticles, J. Colloid Interface Sci. 336 (2009) 510-518

[36] S.C. Hong, J.H. Lee, J. Lee, H.Y. Kim, J.Y. Park, J. Cho, J. Lee, D.W. Han, Subtle cytotoxicity and genotoxicity differences in superparamagnetic iron oxide nanoparticles coated with various functional groups, Int. J. Nanomed. 6 (2011) 3219-3231.

[37] S. Huang, C. Li, Z. Cheng, Y. Fan, P. Yang, C. Zhang, K. Yang, J. Lin, Magnetic $\mathrm{Fe}_{3} \mathrm{O}_{4} @$ mesoporous silica composites for drug delivery and bioadsorption, J. Colloid Interface Sci. 376 (2012) 312-321.

[38] H.L. Karlsson, J. Gustafsson, P. Cronholm, L. Moller, Size-dependent toxicity of metal oxide particles-a comparison between nano- and micrometer size, Toxicol. Lett. 188 (2009) 112-118.

[39] N.J. Schaub, D. Rende, Y. Yuan, R.J. Gilbert, D.A. Borca-Tasciuc, Reduced astrocyte viability at physiological temperatures from magnetically activated iron oxide nanoparticles, Chem. Res. Toxicol. 27 (2014) 2023-2035.

[40] A. Paolini, C.P. Guarch, D. Ramos-Lopez, J. de Lapuente, A. Lascialfari, Y. Guari, J. Larionova, J. Long, R. Nano, Rhamnose-coated superparamagnetic iron-oxide nanoparticles: an evaluation of their in vitro cytotoxicity, genotoxicity and carcinogenicity, J. Appl. Toxicol. 36 (2015) 510-520.

[41] C. Costa, F. Brandao, M.J. Bessa, S. Costa, V. Valdiglesias, G. Kilic, N. Fernandez-Bertolez, P. Quaresma, E. Pereira, E. Pasaro, B. Laffon, J.P. Teixeira, In vitro cytotoxicity of superparamagnetic iron oxide nanoparticles on neuronal and glial cells. Evaluation of nanoparticle interference with viability tests, J. Appl. Toxicol. 36 (2016) 361-372.

[42] S.J. Soenen, M. De Cuyper, Assessing cytotoxicity of (iron oxide-based) nanoparticles: an overview of different methods exemplified with cationic magnetoliposomes, Contrast Media Mol. Imaging 4 (2009) 207-219.

[43] M. Watanabe, M. Yoneda, A. Morohashi, Y. Hori, D. Okamoto, A. Sato, D. Kurioka, T. Nittami, Y. Hirokawa, T. Shiraishi, K. Kawai, H. Kasai, Y. Totsuka, Effects of $\mathrm{Fe}_{3} \mathrm{O}_{4}$ magnetic nanoparticles on A549 cells, Int. J. Mol. Sci. 14 (2013) 15546-15560.

[44] S. Rajiv, J. Jerobin, V. Saranya, M. Nainawat, A. Sharma, P. Makwana, C. Gayathri, L. Bharath, M. Singh, M. Kumar, A. Mukherjee, N. Chandrasekaran, Comparative cytotoxicity and genotoxicity of cobalt(II, III) oxide, iron(III) oxide, silicon dioxide, and aluminum oxide nanoparticles on human lymphocytes in vitro, Hum. Exp. Toxicol. 35 (2016) 170-183.

[45] J. Wu, J. Sun, Investigation on mechanism of growth arrest induced by iron oxide nanoparticles in PC12 cells, J. Nanosci. Nanotechnol. 11 (2011) 11079-11083.

[46] E.J. Park, S.W. Kim, C. Yoon, Y. Kim, J.S. Kim, Disturbance of ion environment and immune regulation following biodistribution of magnetic iron oxide nanoparticles injected intravenously, Toxicol. Lett. 243 (2016) 67-77.

[47] W. Wu, Q. He, C. Jiang, Magnetic iron oxide nanoparticles: synthesis and surface functionalization strategies, Nanoscale Res. Lett. 3 (2008) 397-415.

[48] P. Schutz, M. Bally, Z. Stanga, U. Keller, Loss of appetite in acutely ill medica inpatients: physiological response or therapeutic target? Swiss Med. Wkly. 144 (2014) w13957.

[49] M. Shi, L. Cheng, Z. Zhang, Z. Liu, X. Mao, Ferroferric oxide nanoparticles induce prosurvival autophagy in human blood cells by modulating the Beclin 1/Bcl-2/VPS34 complex, Int. J. Nanomed. 10 (2015) 207-216.

[50] S. Dwivedi, M.A. Siddiqui, N.N. Farshori, M. Ahamed, J. Musarrat, A.A. Al-Khedhairy, Synthesis, characterization and toxicological evaluation of iron oxide nanoparticles in human lung alveolar epithelial cells, Colloids Surf. B Biointerfaces 122 (2014) 209-215

[51] M.T. Zhu, Y. Wang, W.Y. Feng, B. Wang, M. Wang, H. Ouyang, Z.F. Chai, Oxidative stress and apoptosis induced by iron oxide nanoparticles in cultured human umbilical endothelial cells, J. Nanosci. Nanotechnol. 10 (2010) 8584-8590.

[52] S.M. Cromer Berman, Kshitiz, C.J. Wang, I. Orukari, A. Levchenko, J.W. Bulte, P. Walczak, Cell motility of neural stem cells is reduced after SPIO-labeling, which is mitigated after exocytosis, Magn. Reson. Med. 69 (2013) 255-262.

[53] K. Astanina, Y. Simon, C. Cavelius, S. Petry, A. Kraegeloh, A.K. Kiemer, Superparamagnetic iron oxide nanoparticles impair endothelial integrity and inhibit nitric oxide production, Acta Biomater. 10 (2014) 4896-4911.
[54] E. Ying, H.M. Hwang, In vitro evaluation of the cytotoxicity of iron oxide nanoparticles with different coatings and different sizes in A3 human T lymphocytes, Sci. Total Environ. 408 (2010) 4475-4481.

[55] C.J. Rivet, Y. Yuan, D.A. Borca-Tasciuc, R.J. Gilbert, Altering iron oxide nanoparticle surface properties induce cortical neuron cytotoxicity, Chem. Res. Toxicol. 25 (2012) 153-161.

[56] L. Li, K.Y. Mak, J. Shi, H.K. Koon, C.H. Leung, C.M. Wong, C.W. Leung, C.S. Mak, N.M. Chan, W. Zhong, K.W. Lin, E.X. Wu, P.W. Pong, Comparative in vitro cytotoxicity study on uncoated magnetic nanoparticles: effects on cell viability, cell morphology, and cellular uptake, J. Nanosci. Nanotechnol. 12 (2012) 9010-9017.

[57] S.J. Soenen, U. Himmelreich, N. Nuytten, M. De Cuyper, Cytotoxic effects of iron oxide nanoparticles and implications for safety in cell labelling, Biomaterials 32 (2011) 195-205.

[58] Z. Magdolenova, M. Drlickova, K. Henjum, E. Runden-Pran, J. Tulinska, D. Bilanicova, G. Pojana, A. Kazimirova, M. Barancokova, M. Kuricova, A. Liskova, M. Staruchova, F. Ciampor, I. Vavra, Y. Lorenzo, A. Collins, A. Rinna, L. Fjellsbo, K. Volkovova, A. Marcomini, M. Amiry-Moghaddam, M. Dusinska, Coating-dependent induction of cytotoxicity and genotoxicity of iron oxide nanoparticles, Nanotoxicology 9 (Suppl. 1) (2013) 44-56.

[59] D. Couto, M. Freitas, V. Vilas-Boas, I. Dias, G. Porto, M.A. Lopez-Quintela, J. Rivas, P. Freitas, F. Carvalho, E. Fernandes, Interaction of polyacrylic acid coated and non-coated iron oxide nanoparticles with human neutrophils, Toxicol. Lett. 225 (2014) 57-65.

[60] Z. Sun, V. Yathindranath, M. Worden, J.A. Thliveris, S. Chu, F.E. Parkinson, T. Hegmann, D.W. Miller, Characterization of cellular uptake and toxicity of aminosilane-coated iron oxide nanoparticles with different charges in central nervous system-relevant cell culture models, Int. J. Nanomed. 8 (2013) 961-970.

[61] Z. Chen, J.J. Yin, Y.T. Zhou, Y. Zhang, L. Song, M. Song, S. Hu, N. Gu, Dual enzyme-like activities of iron oxide nanoparticles and their implication for diminishing cytotoxicity, ACS Nano 6 (2012) 4001-4012

[62] M. Auffan, W. Achouak, J. Rose, M.A. Roncato, C. Chaneac, D.T. Waite, A. Masion, J.C. Woicik, M.R. Wiesner, J.Y. Bottero, Relation between the redox state of iron-based nanoparticles and their cytotoxicity toward Escherichia coli, Environ. Sci. Technol. 42 (2008) 6730-6735.

[63] K. Buyukhatipoglu, A.M. Clyne, Superparamagnetic iron oxide nanoparticles change endothelial cell morphology and mechanics via reactive oxygen species formation, J. Biomed. Mater. Res. A 96 (2011) 186-195.

[64] L. Sadeghi, V. Yousefi Babadi, H.R. Espanani, Toxic effects of the $\mathrm{Fe}_{2} \mathrm{O}_{3}$ nanoparticles on the liver and lung tissue, Bratisl. Lek. Listy 116 (2015) 373-378.

[65] C.C. Hanot, Y.S. Choi, T.B. Anani, D. Soundarrajan, A.E. David, Effects of iron-oxide nanoparticle surface chemistry on uptake kinetics and cytotoxicity in CHO-K1 cells, Int. J. Mol. Sci. 17 (2015).

[66] S. Naqvi, M. Samim, M. Abdin, F.J. Ahmed, A. Maitra, C. Prashant, A.K. Dinda, Concentration-dependent toxicity of iron oxide nanoparticles mediated by increased oxidative stress, Int. J. Nanomed. 5 (2010) 983-989.

[67] A. Hanini, A. Schmitt, K. Kacem, F. Chau, S. Ammar, J. Gavard, Evaluation of iron oxide nanoparticle biocompatibility, Int. J. Nanomed. 6 (2011) 787-794.

[68] M.T. Zhu, B. Wang, Y. Wang, L. Yuan, H.J. Wang, M. Wang, H. Ouyang, Z.F. Chai, W.Y. Feng, Y.L. Zhao, Endothelial dysfunction and inflammation induced by iron oxide nanoparticle exposure: risk factors for early atherosclerosis, Toxicol. Lett. 203 (2011) 162-171.

[69] T. Zhang, L. Qian, M. Tang, Y. Xue, L. Kong, S. Zhang, Y. Pu, Evaluation on cytotoxicity and genotoxicity of the L-glutamic acid coated iron oxide nanoparticles, J. Nanosci. Nanotechnol. 12 (2012) 2866-2873.

[70] M. Konczol, S. Ebeling, E. Goldenberg, F. Treude, R. Gminski, R. Giere, B. Grobety, B. Rothen-Rutishauser, I. Merfort, V. Mersch-Sundermann, Cytotoxicity and genotoxicity of size-fractionated iron oxide (magnetite) in A549 human lung epithelial cells: role of ROS, JNK, and NF-kappaB, Chem. Res. Toxicol. 24 (2011) 1460-1475.

[71] C. Petters, K. Thiel, R. Dringen, Lysosomal iron liberation is responsible for the vulnerability of brain microglial cells to iron oxide nanoparticles: comparison with neurons and astrocytes, Nanotoxicology (2015) 1-11.

[72] H. Hildebrand, D. Kuhnel, A. Potthoff, K. Mackenzie, A. Springer, K. Schirmer, Evaluating the cytotoxicity of palladium/magnetite nano-catalysts intended for wastewater treatment, Environ. Pollut. 158 (2010) 65-73.

[73] A. Lindemann, K. Ludtke-Buzug, B.M. Fraderich, K. Grafe, R. Pries, B. Wollenberg, Biological impact of superparamagnetic iron oxide nanoparticles for magnetic particle imaging of head and neck cancer cells, Int. J. Nanomed. 9 (2014) 5025-5040.

[74] Y. Wang, B. Wang, M.T. Zhu, M. Li, H.J. Wang, M. Wang, H. Ouyang, Z.F. Chai, W.Y. Feng, Y.L. Zhao, Microglial activation, recruitment and phagocytosis as linked phenomena in ferric oxide nanoparticle exposure, Toxicol. Lett. 205 (2011) 26-37.

[75] B.H. Kenzaoui, C.C. Bernasconi, H. Hofmann, L. Juillerat-Jeanneret, Evaluation of uptake and transport of ultrasmall superparamagnetic iron oxide nanoparticles by human brain-derived endothelial cells, Nanomedicine (Lond.) 7 (2012) 39-53.

[76] M. Hohnholt, M. Geppert, R. Dringen, Effects of iron chelators, iron salts, and iron oxide nanoparticles on the proliferation and the iron content of oligodendroglial OLN-93 cells, Neurochem. Res. 35 (2010) 1259-1268.

[77] M.C. Hohnholt, M. Geppert, R. Dringen, Treatment with iron oxide nanoparticles induces ferritin synthesis but not oxidative stress in oligodendroglial cells, Acta Biomater. 7 (2011) 3946-3954. 
[78] A. Shander, M.D. Cappellini, L.T. Goodnough, Iron overload and toxicity: the hidden risk of multiple blood transfusions, Vox Sang. 97 (2009) 185-197.

[79] M. Geppert, M. Hohnholt, L. Gaetjen, I. Grunwald, M. Baumer, R. Dringen, Accumulation of iron oxide nanoparticles by cultured brain astrocytes, J. Biomed. Nanotechnol. 5 (2009) 285-293.

[80] N. Singh, G.J. Jenkins, R. Asadi, S.H. Doak, Potential toxicity of superparamagnetic iron oxide nanoparticles (SPION), Nano Rev. 1 (2010).

[81] M.C. Hohnholt, R. Dringen, Uptake and metabolism of iron and iron oxide nanoparticles in brain astrocytes, Biochem. Soc. Trans. 41 (2013) 1588-1592.

[82] D.W. Reif, Ferritin as a source of iron for oxidative damage, Free Radic. Biol. Med. 12 (1992) 417-427.

[83] M. Valko, D. Leibfritz, J. Moncol, M.T. Cronin, M. Mazur, J. Telser, Free radicals and antioxidants in normal physiological functions and human disease, Int. J. Biochem. Cell Biol. 39 (2007) 44-84.

[84] J. Kain, H.L. Karlsson, L. Moller, DNA damage induced by micro- and nanoparticles-interaction with FPG influences the detection of DNA oxidation in the comet assay, Mutagenesis 27 (2012) 491-500.

[85] I.O. Gomaa, M.H. Kader, T.A. Salah, O.A. Heikal, Evaluation of in vitro mutagenicity and genotoxicity of magnetite nanoparticles, Drug Discov. Ther. 7 (2013) 116-123.

[86] M. Ahamed, H.A. Alhadlaq, J. Alam, M.A. Khan, D. Ali, S. Alarafi, Iron oxide nanoparticle-induced oxidative stress and genotoxicity in human skin epithelial and lung epithelial cell lines, Curr. Pharm. Des. 19 (2013) 6681-6690.

[87] K. Bhattacharya, M. Davoren, J. Boertz, R.P. Schins, E. Hoffmann, E. Dopp, Titanium dioxide nanoparticles induce oxidative stress and DNA-adduct formation but not DNA-breakage in human lung cells, Part. Fibre Toxicol. 6 (2009) 17.

[88] N. Singh, G.J. Jenkins, B.C. Nelson, B.J. Marquis, T.G. Maffeis, A.P. Brown, P.M. Williams, C.J. Wright, S.H. Doak, The role of iron redox state in the genotoxicity of ultrafine superparamagnetic iron oxide nanoparticles, Biomaterials 33 (2012) 163-170.

[89] M. Mesarosova, K. Kozics, A. Babelova, E. Regendova, M. Pastorek, D. Vnukova, B. Buliakova, F. Razga, A. Gabelova, The role of reactive oxygen species in the genotoxicity of surface-modified magnetite nanoparticles, Toxicol. Lett. 226 (2014) 303-313.

[90] H.L. Karlsson, P. Cronholm, J. Gustafsson, L. Moller, Copper oxide nanoparticles are highly toxic: a comparison between metal oxide nanoparticles and carbon nanotubes, Chem. Res. Toxicol. 21 (2008) $1726-1732$

[91] Y. Guichard, J. Schmit, C. Darne, L. Gate, M. Goutet, D. Rousset, O. Rastoix, R. Wrobel, O. Witschger, A. Martin, V. Fierro, S. Binet, Cytotoxicity and genotoxicity of nanosized and microsized titanium dioxide and iron oxide particles in Syrian hamster embryo cells, Ann. Occup. Hyg. 56 (2012) 631-644.

[92] Y. Liu, Q. Xia, Y. Liu, S. Zhang, F. Cheng, Z. Zhong, L. Wang, H. Li, K. Xiao, Genotoxicity assessment of magnetic iron oxide nanoparticles with different particle sizes and surface coatings, Nanotechnology 25 (2014) 425101.

[93] M. Auffan, L. Decome, J. Rose, T. Orsiere, M. De Meo, V. Briois, C. Chaneac, L. Olivi, J.L. Berge-Lefranc, A. Botta, M.R. Wiesner, J.Y. Bottero, In vitro interactions between DMSA-coated maghemite nanoparticles and human fibroblasts: a physicochemical and cyto-genotoxical study, Environ. Sci. Technol. 40 (2006) 4367-4373.

[94] R. Weissleder, D.D. Stark, B.L. Engelstad, B.R. Bacon, C.C. Compton, D.L. White, P. Jacobs, J. Lewis, Superparamagnetic iron oxide: pharmacokinetics and toxicity, AJR Am. J. Roentgenol. 152 (1989) 167-173.

[95] P. Bourrinet, H.H. Bengele, B. Bonnemain, A. Dencausse, J.M. Idee, P.M. Jacobs, J.M. Lewis, Preclinical safety and pharmacokinetic profile of ferumoxtran-10, an ultrasmall superparamagnetic iron oxide magnetic resonance contrast agent, Invest. Radiol. 41 (2006) 313-324.

[96] S.S. Teske, C.S. Detweiler, The biomechanisms of metal and metal-oxide nanoparticles' interactions with cells, Int. J. Environ. Res. Public Health 12 (2015) 1112-1134

[97] K. Volkovova, R.D. Handy, M. Staruchova, J. Tulinska, A. Kebis, J. Pribojova, O. Ulicna, J. Kucharska, M. Dusinska, Health effects of selected nanoparticles in vivo: liver function and hepatotoxicity following intravenous injection of titanium dioxide and $\mathrm{Na}$-oleate-coated iron oxide nanoparticles in rodents, Nanotoxicology 9 (Suppl. 1) (2015) 95-105.

[98] S.P. Singh, M.F. Rahman, U.S. Murty, M. Mahboob, P. Grover, Comparative study of genotoxicity and tissue distribution of nano and micron sized iron oxide in rats after acute oral treatment, Toxicol. Appl. Pharmacol. 266 (2013) 56-66.

[99] J.W. Yun, S.H. Kim, J.R. You, W.H. Kim, J.J. Jang, S.K. Min, H.C. Kim, D.H. Chung, J. Jeong, B.C. Kang, J.H. Che, Comparative toxicity of silicon dioxide, silver and iron oxide nanoparticles after repeated oral administration to rats, J. Appl. Toxicol. 35 (2015) 681-693.

[100] J.W. Yun, J.H. Yoon, B.C. Kang, N.H. Cho, S.H. Seok, S.K. Min, J.H. Min, J.H. Che, Y.K. Kim, The toxicity and distribution of iron oxide-zinc oxide core-shell nanoparticles in C57BL/6 mice after repeated subcutaneous administration, J. Appl. Toxicol. 35 (2015) 593-602.

[101] S. Chamorro, L. Gutierrez, M.P. Vaquero, D Verdoy, G. Salas, Y Luengo, A. Brenes, F. Jose Teran, Safety assessment of chronic oral exposure to iron oxide nanoparticles, Nanotechnology 26 (2015) 205101.

[102] A. Al Faraj, A.P. Shaik, A.S. Shaik, Effect of surface coating on the biocompatibility and in vivo MRI detection of iron oxide nanoparticles after intrapulmonary administration, Nanotoxicology 9 (2015) 825-834.
[103] P. Ma, Q. Luo, J. Chen, Y. Gan, J. Du, S. Ding, Z. Xi, X. Yang, Intraperitoneal injection of magnetic $\mathrm{Fe}_{3} \mathrm{O}_{4}$-nanoparticle induces hepatic and renal tissue injury via oxidative stress in mice, Int J. Nanomed. 7 (2012) 4809-4818.

[104] M.L.L. Freitas, L.P. Silva, R.B. Azevedo, V.A.P. Garcia, L.M. Lacava, C.K. GrisÃ3lia, C.M. Lucci, P.C. Morais, M.F. Da Silva, N. Buske, R. Curi, Z.G.M. Lacava, A double-coated magnetite-based magnetic fluid evaluation by cytometry and genetic tests, J. Magn. Magn. Mater. 252 (2002) 396-398.

[105] N. Sadeghiani, L.S. Barbosa, L.P. Silva, R.B. Azevedo, P.C. Morais, Z.G.M. Lacava, Genotoxicity and inflammatory investigation in mice treated with magnetite nanoparticles surface coated with polyaspartic acid, J. Magn. Magn. Mater. 289 (2005) 466-468.

[106] Z. Lin, N.A. Monteiro-Riviere, J.E. Riviere, Pharmacokinetics of metallic nanoparticles, Wiley Interdiscip. Rev. Nanomed. Nanobiotechnol. 7 (2015) 189-217.

[107] E. Ansciaux, C. Burtea, S. Laurent, D. Crombez, D. Nonclercq, L. Vander Elst, R.N. Muller, In vitro and in vivo characterization of several functionalized ultrasmall particles of iron oxide, vectorized against amyloid plaques and potentially able to cross the blood-brain barrier: toward earlier diagnosis of Alzheimer's disease by molecular imaging, Contrast Media Mol. Imaging 10 (2015) 211-224

[108] L. Yang, H. Kuang, W. Zhang, Z.P. Aguilar, Y. Xiong, W. Lai, H. Xu, H. Wei, Size dependent biodistribution and toxicokinetics of iron oxide magnetic nanoparticles in mice, Nanoscale 7 (2015) 625-636.

[109] M. Kumari, S. Rajak, S.P. Singh, S.I. Kumari, P.U. Kumar, U.S. Murty, M. Mahboob, P. Grover, M.F. Rahman, Repeated oral dose toxicity of iron oxide nanoparticles: biochemical and histopathological alterations in different tissues of rats, J. Nanosci. Nanotechnol. 12 (2012) 2149-2159.

[110] E.J. Park, S.Y. Oh, Y. Kim, C. Yoon, B.S. Lee, S.D. Kim, J.S. Kim, Distribution and immunotoxicity by intravenous injection of iron nanoparticles in a murine model, J. Appl. Toxicol. 36 (2016) 414-423.

[111] D. Kwon, H.W. Nho, T.H. Yoon, X-ray and electron microscopy studies on the biodistribution and biomodification of iron oxide nanoparticles in Daphnia magna, Colloids Surf. B Biointerfaces 122 (2014) 384-389.

[112] M. Radu Balas, I.M. Din Popescu, A. Hermenean, O.L. Cinteza, R. Burlacu, A. Ardelean, A. Dinischiotu, Exposure to iron oxide nanoparticles coated with phospholipid-based polymeric micelles induces biochemical and histopathological pulmonary changes in mice, Int. J. Mol. Sci. 16 (2015) 29417-29435.

[113] Y. Baratli, A.L. Charles, V. Wolff, L. Ben Tahar, L. Smiri, J. Bouitbir, J. Zoll, M. Sakly, C. Auger, T. Vogel, H. Abdelmelek, O. Tebourbi, B. Geny, Age modulates $\mathrm{Fe}_{3} \mathrm{O}_{4}$ nanoparticles liver toxicity: dose-dependent decrease in mitochondrial respiratory chain complexes activities and coupling in middle-aged as compared to young rats, Biomed Res. Int. 2014 (2014) 474081.

[114] A. Gustafsson, U. Bergstrom, L. Agren, L. Osterlund, T. Sandstrom, A. Bucht, Differential cellular responses in healthy mice and in mice with established airway inflammation when exposed to hematite nanoparticles, Toxicol. Appl. Pharmacol. 288 (2015) 1-11.

[115] Y. Totsuka, K. Ishino, T. Kato, S. Goto, Y. Tada, D. Nakae, M. Watanabe, K. Wakabayashi, Magnetite nanoparticles induce genotoxicity in the lungs of mice via inflammatory response, Nanomaterials 4 (2014) 175-188.

[116] K. Ishino, T. Kato, M. Kato, T. Shibata, M. Watanabe, K. Wakabayashi, H. Nakagama, Y. Totsuka, Comprehensive DNA adduct analysis reveals pulmonary inflammatory response contributes to genotoxic action of magnetite nanoparticles, Int. J. Mol. Sci. 16 (2015) 3474-3492.

[117] L. Estevanato, D. Cintra, N. Baldini, F. Portilho, L. Barbosa, O. Martins, B. Lacava, A.L. Miranda-Vilela, A.C. Tedesco, S. Bao, P.C. Morais, Z.G. Lacava, Preliminary biocompatibility investigation of magnetic albumin nanosphere designed as a potential versatile drug delivery system, Int. J. Nanomed. 6 (2011) 1709-1717

[118] D. Chen, Q. Tang, X. Li, X. Zhou, J. Zang, W.Q. Xue, J.Y. Xiang, C.Q. Guo, Biocompatibility of magnetic $\mathrm{Fe}_{3} \mathrm{O}_{4}$ nanoparticles and their cytotoxic effect on MCF-7 cells, Int. J. Nanomed. 7 (2012) 4973-4982.

[119] N. Singh, B. Manshian, G.J. Jenkins, S.M. Griffiths, P.M. Williams, T.G. Maffeis, C.J. Wright, S.H. Doak, NanoGenotoxicology: the DNA damaging potential of engineered nanomaterials, Biomaterials 30 (2009) 3891-3914.

[120] J. Zhao, V. Castranova, Toxicology of nanomaterials used in nanomedicine, J. Toxicol. Environ. Health B Crit. Rev. 14 (2011) 593-632.

[121] Z. Magdolenova, Y. Lorenzo, A. Collins, M. Dusinska, Can standard genotoxicity tests be applied to nanoparticles? J. Toxicol. Environ. Health A 75 (2012) 800-806.

[122] G. Kiliç, N. Fernández-Bertólez, C. Costa, S. Costa, J.P. Teixeira, E. Pásaro, B. Laffon, V. Valdiglesias, Effects of sílica-coated iron oxide nanoparticles on SH-SY5Y cells, Toxicol. Res. 5 (2016) 235-247.

[123] J. Wang, Y. Chen, B. Chen, J. Ding, G. Xia, C. Gao, J. Cheng, N. Jin, Y. Zhou, X. Li M. Tang, X.M. Wang, Pharmacokinetic parameters and tissue distribution of magnetic $\mathrm{Fe}_{3} \mathrm{O}_{4}$ nanoparticles in mice, Int. J. Nanomed. 5 (2010) 861-866.

[124] J.S. Kim, T.J. Yoon, K.N. Yu, B.G. Kim, S.J. Park, H.W. Kim, K.H. Lee, S.B. Park, J.K. Lee, M.H. Cho, Toxicity and tissue distribution of magnetic nanoparticles in mice, Toxicol. Sci. 89 (2006) 338-347.

[125] J. Wang, B. Chen, N. Jin, G. Xia, Y. Chen, Y. Zhou, X. Cai, J. Ding, X. Li, X. Wang, The changes of $\mathrm{T}$ lymphocytes and cytokines in ICR mice fed with $\mathrm{Fe}_{3} \mathrm{O}_{4}$ magnetic nanoparticles, Int. J. Nanomed. 6 (2011) 605-610.

[126] W. Wu, B. Chen, J. Cheng, J. Wang, W. Xu, L. Liu, G. Xia, H. Wei, X. Wang, M. Yang, L. Yang, Y. Zhang, C. Xu, J. Li, Biocompatibility of $\mathrm{Fe}_{3} \mathrm{O}_{4} /$ DNR magnetic 
nanoparticles in the treatment of hematologic malignancies, Int. J. Nanomed. 5 (2010) 1079-1084.

[127] Y. Kim, S.D. Kong, L.H. Chen, T.R. Pisanic 2nd, S. Jin, V.I. Shubayev, In vivo nanoneurotoxicity screening using oxidative stress and neuroinflammation paradigms, Nanomedicine 9 (2013) 1057-1066

[128] B. Wang, W.Y. Feng, M. Wang, J.W. Shi, F. Zhang, H. Ouyang, Y.L. Zhao, Z.F. Chai, Y.Y. Huang, Y.N. Xie, H.F. Wang, J. Wang, Transport of intranasally instilled fine $\mathrm{Fe}_{2} \mathrm{O}_{3}$ particles into the brain: micro-distribution, chemical states, and histopathological observation, Biol. Trace Elem. Res. 118 (2007) $233-243$.

[129] G.M. de Oliveira, L.W. Kist, T.C. Pereira, J.W. Bortolotto, F.L. Paquete, E.M. de Oliveira, C.E. Leite, C.D. Bonan, N.R. de Souza Basso, R.M. Papaleo, M.R. Bogo, Transient modulation of acetylcholinesterase activity caused by exposure to dextran-coated iron oxide nanoparticles in brain of adult zebrafish, Comp. Biochem. Physiol. C Toxicol. Pharmacol. 162 (2014) 77-84.

[130] E.J. Park, D.H. Choi, Y. Kim, E.W. Lee, J. Song, M.H. Cho, J.H. Kim, S.W. Kim, Magnetic iron oxide nanoparticles induce autophagy preceding apoptosis through mitochondrial damage and ER stress in RAW264.7 cells, Toxicol. In Vitro 28 (2014) 1402-1412.

[131] S.L. Easo, P.V. Mohanan, In vitro hematological and in vivo immunotoxicity assessment of dextran stabilized iron oxide nanoparticles, Colloids Surf. B Biointerfaces 134 (2015) 122-130.

[132] S. Nations, M. Wages, J.E. Canas, J. Maul, C. Theodorakis, G.P. Cobb, Acute effects of $\mathrm{Fe}_{2} \mathrm{O}_{3}, \mathrm{TiO}_{2}, \mathrm{ZnO}$ and $\mathrm{CuO}$ nanomaterials on Xenopus laevis, Chemosphere 83 (2011) 1053-1061.

[133] A. Noori, K. Parivar, M. Modaresi, M. Messripour, M.H. Yousefi, G.R. Amiri, Effect of magnetic iron oxide nanoparticles on pregnancy and testicular development of mice, Afr. J. Biotechnol. 10 (2011) 1221-1227.
[134] X. Zhu, S. Tian, Z. Cai, Toxicity assessment of iron oxide nanoparticles in zebrafish (Danio rerio) early life stages, PLoS One 7 (2012) e46286.

[135] C.C. Piccinetti, C. Montis, M. Bonini, R. Laura, M.C. Guerrera, G. Radaelli, F. Vianello, V. Santinelli, F. Maradonna, V. Nozzi, A. Miccoli, I. Olivotto, Transfer of silica-coated magnetic $\left(\mathrm{Fe}_{3} \mathrm{O}_{4}\right)$ nanoparticles through food: a molecular and morphological study in zebrafish, Zebrafish 11 (2014) 567-579.

[136] K.R. Di Bona, Y. Xu, P.A. Ramirez, J. DeLaine, C. Parker, Y. Bao, J.F. Rasco, Surface charge and dosage dependent potential developmental toxicity and biodistribution of iron oxide nanoparticles in pregnant CD-1 mice, Reprod. Toxicol. 50 (2014) 36-42.

[137] K.R. Di Bona, Y. Xu, M. Gray, D. Fair, H. Hayles, L. Milad, A. Montes, J. Sherwood, Y. Bao, J.F. Rasco, Short- and long-term effects of prenatal exposure to iron oxide nanoparticles: influence of surface charge and dose on developmental and reproductive toxicity, Int. J. Mol. Sci. 16 (2015) 30251-30268.

[138] L.M.H. Schmoll, Occupational Nanoparticle Exposure, University of Hong Kong, 2008, pp. 1-127.

[139] S.T. Stern, S.E. McNeil, Nanotechnology safety concerns revisited, Toxicol. Sci. 101 (2008) 4-21.

[140] M. Xing, Y. Zhang, H. Zou, C. Quan, B. Chang, S. Tang, M. Zhang, Exposure characteristics of ferric oxide nanoparticles released during activities for manufacturing ferric oxide nanomaterials, Inhal. Toxicol. 27 (2015) $138-148$.

[141] D. Pelclova, V. Zdimal, P. Kacer, Z. Fenclova, S. Vlckova, K. Syslova, T. Navratil, J. Schwarz, N. Zikova, H. Barosova, F. Turci, M. Komarc, T. Pelcl, J. Belacek, J. Kukutschova, S. Zakharov, Oxidative stress markers are elevated in exhaled breath condensate of workers exposed to nanoparticles during iron oxide pigment production, J. Breath Res. 10 (2016) 016004. 